\title{
QUANTITATIVE ANALYSIS OF SODIUM PICOSULFATE IN THE PRESENCE OF ITS ALKALINE DEGRADATION PRODUCT
}

\author{
Ivana Savić, Goran Nikolić, Ivan Savić \\ Department of Pharmaceutics, Faculty of Technology, \\ Bulevar oslobodjenja 124, Leskovac 16000, Serbia \\ ici86@info-net.rs
}

\begin{abstract}
A new procedure for the analytical control of a pharmaceutical formulation by high performance liquid chromatographic (HPLC) is proposed. It allows the simultaneous determination of the major compounds in the formulation of the active compound (sodium picosulfate) and the degradation product (impurity), which slowly degrades by hydrolysis with different concentrations of sodium hydroxide, at different temperatures. Separation of sodium picosulfate from the degradation product was performed using the ZORBAX Eclipse XDB C-18 column, with a mobile phase consisting of phosphate buffer $(\mathrm{pH}=7)$ : acetonitrile $85: 15 \mathrm{v} / \mathrm{v}$. The method was validated using the HPLC procedure, evaluating selectivity, accuracy, linearity and precision. The proposed method was successfully applied, with excellent recovery, to the analysis of a pharmaceutical formulation (Sodium picosulfate, Zdravlje-Actavis, Serbia) containing sodium picosulfate.
\end{abstract}

Key words: sodium picosulfate; alkaline degradation; HPLC; kinetics

\section{КВАНТИТАТИВНА АНАЛИЗА НА НАТРИУМПИКОСУЛФАТ ВО ПРИСУСТВО НА НЕГОВИОТ АЛКАЛЕН ДЕГРАДАЦИОНЕН ПРОДУКТ}

\begin{abstract}
Bo трудот е предложена нова постапка за аналитичка контрола на фармацевтска формулација со HPLC. Со неа е овозможено истовремено определување на активната компонента натриумпикосулфат во формулацијата и на деградациониот продукт, добиен со хидролиза при различни концентрации на натриумхидроксид, на различни температури. Одвојувањето на пикосулфатот од деградациониот продукт е постигнато со употреба на колоната ZORBAX Eclipse XDB C-18, со мобилна фаза, составот на фосфатниот пуфер $(\mathrm{pH}=7)$ : ацетонитрилот 85:15 v/v; Методот е валидиран со употреба на HPLC и со одредување на селективноста, точноста, линеарноста и прецизноста. Предложениот метод успешно е применет со висока рекуперација при анализа на фармацевтска формулација (натриумпикосулфат, Здравље-Актавис, Србија).
\end{abstract}

Клучни зборови: натриумпикосулфат; алкална деградација; HPLC; кинетика

\section{INTRODUCTION}

Sodium picosulfate $\left(4,4^{\prime}-(2\right.$-pyridylmethylene) diphenil bis(hydrogen sulfate)disodium) is a medicine known as a stimulant laxative. After being taken by mouth, it is activated by the bacteria naturally present in the large intestine. It then stimulates nerve endings in the intestinal wall. These nerves make the muscles in the intestine and the rectum contract more often and with more force, a process known as peristalsis. This moves the contents of the intestine along so that the bowel can be emptied, and hence relieves constipation. Sodium picosulfate is also used to stimulate the emptying of the bowel before surgery, childbirth or medical investigation of the gut.

The HPLC is not yet an official method in any pharmacopoeia for the analysis of sodium picosulfate $[1,2]$. The analysis of sodium picosulfate in bulk drugs and pharmaceutical products is well described in the literature [3-11], but the HPLC method for determination of sodium picosulfate in 
presence of its impurity (degradation product) has not been described.

The present work aimed to develop validation of a new RP-HPLC feasible, sensitive and specific analytical procedure. The procedure is suitable for application in a drug quality control or regulatory laboratory analysis of sodium picosulfate, in the presence of its degradation product. The analysis of degradation product obtained during the alkaline hydrolysis in sodium hydroxide solutions with various concentrations, at different temperatures, was presented in this paper. The developed analytical method was validated as per International Conference on Harmonization guidelines [12] and Serbian requirements [13]. Statistical tests were performed on validation data [14]. The validation consists of testing the method selectivity towards components and the assessment of the method precision, trueness and accuracy $[15,18]$ at different concentration levels over the range investigated, as well as the confirmation of the limit of quantitation (LOQ) and the method linearity [15-17]. Adaptation of the proposed procedure for the analysis of the available dosage form, including expired ones, is also an important task in order to solve problems encountered in the quality control. Moreover, kinetic studies and accelerated stability experiments to predict expiry dates of pharmaceutical products necessitate such methods.

\section{EXPERIMENTAL}

Samples. Standard substances of sodium picosulfate and sodium-4-((2-pyridinyl)(4-hydroxiphenyl) methyl) phenylsulfat), as well as Sodium picosulfate tablets were kindly supplied by Zdravlje-Actavis, Leskovac. Each tablet is claimed to contain $5 \mathrm{mg}$ of sodium picosulfate.

Reagents. All chemicals used were of analytical grade and deionized water was HPLC grade. Disodium hydrogen phosphate, kalium dihydrogen phosphate and acetonitrile for HPLC were obtained from Merck, N.J., U.S.A.

Apparatus. The method development was performed with an Agilent 1100-Series HPLC system consisting of an Agilent 1100-Series variable wavelength UV detector and an Agilent 1100Series auto-sampler using a $50 \mu \mathrm{l}$ sample loop (Faculty of Technology, Leskovac). The system was controlled and data analyses were performed with the Agilent HPLC Data Analysis software.
The assays (reproducibility) were performed with another LC system consisting of an Agilent 1100Series binary pump and an Agilent 1100-Series DAD detector (Zdravlje-Actavis, Leskovac). The detector was set at $263 \mathrm{~nm}$ and the peak areas were integrated automatically by the computer using the Agilent HPLC Data Analysis software program. The separation was carried out at ambient temperature using a ZORBAX Eclipse XDB-C18 column, $(4.6 \times 250 \mathrm{~mm}, 5 \mu \mathrm{m})$. All the calculations concerning the quantitative analysis were performed with the external standardization by measuring the peak areas.

Chromatographic conditions. RP-HPLC analysis was performed by isocratic elution with a flow rate of $1.5 \mathrm{~cm}^{3} \mathrm{~min}^{-1}$. A mobile phase consisted of phosphate buffer in water : acetonitrile $85: 15 \mathrm{v} / \mathrm{v}$, phosphate buffer: transfer $0.5 \mathrm{~g}$ disodium hydrogen phosphate and $0.301 \mathrm{~g}$ kalium dihydrogen phosphate to a $1 \mathrm{dm}^{3}$ flask and dissolve in water. All solvents were filtered through a $0.45 \mu \mathrm{m}$ millipore filter. Volumes of $50 \mu \mathrm{L}$ of the solutions and samples prepared were injected into the column. Quantification was effected by measuring at 263 $\mathrm{nm}$ as established from the 3-D chromatogram. Throughout the study, the suitability of the chromatographic system was monitored by calculating the capacity factor $\left(\mathrm{k}^{\prime}\right)$, the selectivity $(\alpha)$ and the peak asymmetry $\left(\mathrm{A}_{\mathrm{s}}\right)$.

Procedures. For preparing different concentrations, aliquots of the stock solution were transferred into a series of $10 \mathrm{~cm}^{3}$ standard volumetric flasks and the volumes were made with the respective media. Ten different concentrations were prepared in the range of $10-100 \mu \mathrm{gcm}^{-3}$ of sodium picosulfate in the mobile phase for a standard curve. The final concentrations of sodium picosulfate in the samples were calculated by comparing the sample and the standard peak obtained with the average of three injections of standard solutions.

For studying the kinetic order of the reaction in a $100 \mathrm{~cm}^{3}$ volumetric flask was dissolved $10 \mathrm{mg}$ of sodium picosulfate in $\mathrm{NaOH}\left(0.5\right.$ moldm $\left.^{-3}\right)$ and completed to the mark with the same solvent. This solution was transferred into another clean dry conical flask and refluxed in a thermostatically controlled water bath at $40{ }^{\circ} \mathrm{C}$ for 30 minutes. One $\mathrm{cm}^{3}$ of samples were taken at 1 minute intervals and neutralized with $1 \mathrm{~cm}^{3}$ of 0.5 moldm$^{-3}$ of $\mathrm{HCl}$. The solutions were injected in the liquid chromatograph using the chromatographic conditions described above. The concentration of sodium 
picosulfate was calculated from the regression equation. The $\log \%$ of sodium picosulfate was ploted remaining against time.

For studying the effect of $\mathrm{NaOH}$ concentrations and temperatures on the reaction rate in a $100 \mathrm{~cm}^{3}$ volumetric flask was dissolved $10 \mathrm{mg}$ of sodium picosulfate in $0.1,0.5$ and 1.0 moldm $^{-3}$ $\mathrm{NaOH}$ and completed to the mark with the same solvent. This solution was transferred into another clean dry conical flask and refluxed in a thermostatically controlled water bath at 25,40 or $60{ }^{\circ} \mathrm{C}$ for 30 minutes. One $\mathrm{cm}^{3}$ of samples were taken at 5 minutes intervals and then completed as described in the section for kinetic order of the reaction. The $\log \%$ of sodium picosulfate was ploted remaining against time for different concentrations of $\mathrm{NaOH}$ and different temperatures. The rate constant was calculated, and ploted the Arrhenius plot for the effect of temperature on the rate of hydrolysis.

The accuracy of the method is the closeness of the measured value to the true value for the sample. To determine the accuracy of the proposed method, different levels of drug concentrationslower concentration (LC, 80\%), intermediate concentration (IC, 100\%) and higher concentration (HC, 120\%), were prepared from independent stock solutions and analyzed $(n=10)$. Accuracy was assessed as the percentage relative error and mean $\%$ recovery (Table 1 ). To provide an additional support to the accuracy of the developed assay method, the standard addition method was employed, which involved the addition of different concentrations of pure drug $\left(10,20\right.$ and $\left.30 \mu \mathrm{gcm}^{-3}\right)$ to a known preanalyzed formulation sample and the total concentration was determined using the proposed methods $(n=0)$. The $\%$ recovery of the added pure drug was calculated as $\%$ recovery $=$ $\left[\left(C_{t}-C_{s}\right) / C_{a}\right] \times 100$, where $C_{t}$ is the total drug concentration measured after standard addition; $C_{s}$, drug concentration in the formulation sample; $C_{a}$, drug concentration added to the formulation (Table 2).

The reproducibility was determined by using different levels of drug concentrations (the same concentration levels taken in the accuracy study), prepared from independent stock solutions and analyzed $(n=10)$ (Table 1$)$. Inter-day, intra-day and inter-instrument variations were studied to determine the intermediate precision of the proposed analytical methods. Different levels of drug concentrations in triplicates were prepared three different times in a day and studied for the intraday variation. The same procedure was followed for three different days in order to study the interday variation $(n=10)$. One set of different levels of the concentrations was reanalyzed using another HPLC Agilent 1100-Series system, by proposed methods to study the inter-instrument variation $(n=10)$. The percent relative standard deviation (\% R.S.D.) of the predicted concentrations from the regression equation was taken as precision (Table 3). The precision studies were also carried out by using the real samples of sodium picosulfate in a similar way to a standard solution to prove the usefulness of method.

\section{Table 1}

Accuracy and the precision data for the developed method $(n=10)$

\begin{tabular}{|c|c|c|c|c|}
\hline \multirow[t]{2}{*}{ Level } & \multicolumn{2}{|c|}{$\begin{array}{l}\text { Predicted concentration } \\
\qquad\left(\mu \mathrm{gcm}^{-3}\right)\end{array}$} & \multirow{2}{*}{$\begin{array}{c}\text { Mean } \\
\text { recovery } \\
\%\end{array}$} & \multirow{2}{*}{$\begin{array}{c}\text { Accuracy } \\
(\%)\end{array}$} \\
\hline & Mean $( \pm$ S.D $)$ & \% R.S.D. & & \\
\hline $\begin{array}{c}\text { LC } \\
\left(40 \mu \mathrm{gcm}^{-3}\right)\end{array}$ & $40.23 \pm 0.33$ & 0.81 & 100.57 & 0.57 \\
\hline $\begin{array}{c}\mathrm{IC} \\
\left(50 \mu \mathrm{gcm}^{-3}\right)\end{array}$ & $50.21 \pm 0.34$ & 0.67 & 100.42 & 0.42 \\
\hline $\begin{array}{c}\mathrm{HC} \\
\left(60 \mu \mathrm{gcm}^{-3}\right)\end{array}$ & $59.92 \pm 0.32$ & 0.53 & 99.87 & -0.13 \\
\hline
\end{tabular}

Table 2

Standard addition of sodium picosulfate for accuracy $(n=10)$

\begin{tabular}{cccc}
\hline \hline $\begin{array}{c}\text { Concentration } \\
\left(\mu \mathrm{gcm}^{-3}\right)\end{array}$ & $\begin{array}{c}\text { Pure drug } \\
\text { added } \\
\left(\mu \mathrm{gcm}^{-3}\right)\end{array}$ & $\begin{array}{c}\text { Total drug } \\
\text { found } \\
\left(\mu \mathrm{gcm}^{-3}\right)( \pm \text { S.D })\end{array}$ & $\begin{array}{c}\text { \% recovery } \\
( \pm \text { R.S.D })\end{array}$ \\
\hline 50 & 0 & $50.21 \pm 0.34$ & $100.42 \pm 0.67$ \\
50 & 10 & $59.92 \pm 0.32$ & $99.87 \pm 0.58$ \\
50 & 20 & $70.35 \pm 0.45$ & $100.50 \pm 0.64$ \\
50 & 30 & $79.87 \pm 0.42$ & $99.84 \pm 0.53$ \\
\hline \hline
\end{tabular}

Procedure for tablets. A total of 20 tablets of studied pharmaceutical preparation (Sodium picosulfate, Zdravlje-Actavis, Leskovac, Serbia) containing sodium picosulfate were weighed and finely powdered using a pestle and mortar. An accurately weighed quantity of the resulting powder, equivalent to $5 \mathrm{mg}$ (weight of one tablet) of sodium picosulfate was dissolved in $10 \mathrm{~cm}^{3}$ of methanol. Then it was filtered directly into a 10 $\mathrm{cm}^{3}$ standard volumetric flask. For HPLC determination, aliquots $\left(1 \mathrm{~cm}^{3}\right)$ of sodium picosulfate were 
taken and suitably diluted with the mobile phase in order to get a $50 \mu \mathrm{gcm}^{-3}$ concentration and the samples were injected into the chromatograph.

Comparative method. The employed procedures for the comparative method (potentiometric titration) is described in the European Pharmacopoeia [1].

\section{RESULTS AND DISCUSSION}

\section{HPLC analysis}

A simple isocratic HPLC method is described for the determination of sodium picosulfate in the presence of its degradation product without prior separation. During the optimization of the method two columns (ZORBAX Eclipse XDB-C8 column, $4.6 \times 250 \mathrm{~mm}$ and ZORBAX XDB-C18 column, $4.6 \times 250 \mathrm{~mm}$ ), three solvents (bufrer : acetonitrile : methanol) with differention ratios (40:30:30, 60:20:20, 50:40:10, 40:50:10 and 85:15:0 v/v), three wavelengths $(250,263$ and $270 \mathrm{~nm})$ and four flow rates $\left(0.5,1.0,1.5\right.$ and $\left.2 \mathrm{~cm}^{3} \mathrm{~min}^{-1}\right)$ were tested.
It was found that the ZORBAX Eclipse XDBC18 column $(4.6 \times 250 \mathrm{~mm})$, with a particle size of $5 \mu \mathrm{m}$ gave the most suitable resolution. Satisfactory separation of used standards was obtained with a mobile phase consisting of $0.05 \%$ disodium hydrogen phosphate and $0.0301 \%$ kalium dihydrogen phosphate in water : acetonitrile $(85: 15: 0 \mathrm{v} / \mathrm{v})$. A flow rate of $1.5 \mathrm{~cm}^{3} \mathrm{~min}^{-1}$ gave an optimal signal to the noise ratio with a reasonable separation time. The maximum absorption of sodium picosulfate was detected at $263 \mathrm{~nm}$ and this wavelength was chosen for the analysis.

The corresponding HPLC chromatogram of standard sodium picosulfate and the HPLC chromatograms of its products after alkaline hydrolysis $\left(0.5\right.$ moldm $\left.^{-3} \mathrm{NaOH}\right)$ at $40{ }^{\circ} \mathrm{C}$, recorded at $263 \mathrm{~nm}$, are shown in Fig. 1.

The obtained compounds during alkaline hydrolysis were identified by using the adequate standard. At retention time of 1.454 min was identified sodium picosulfate and at $2.578 \mathrm{~min}$ was noticeable its alkaline degradation product sodium-4-((2-pyridinyl)(4-hydroxiphenyl)methyl) phenylsulfat) (Fig. 1c). Based on the identified degradation product (impurity A), the proposed scheme for preparing the degradation product of sodium picosulfate by alkaline hydrolysis is shown in Fig. 2.

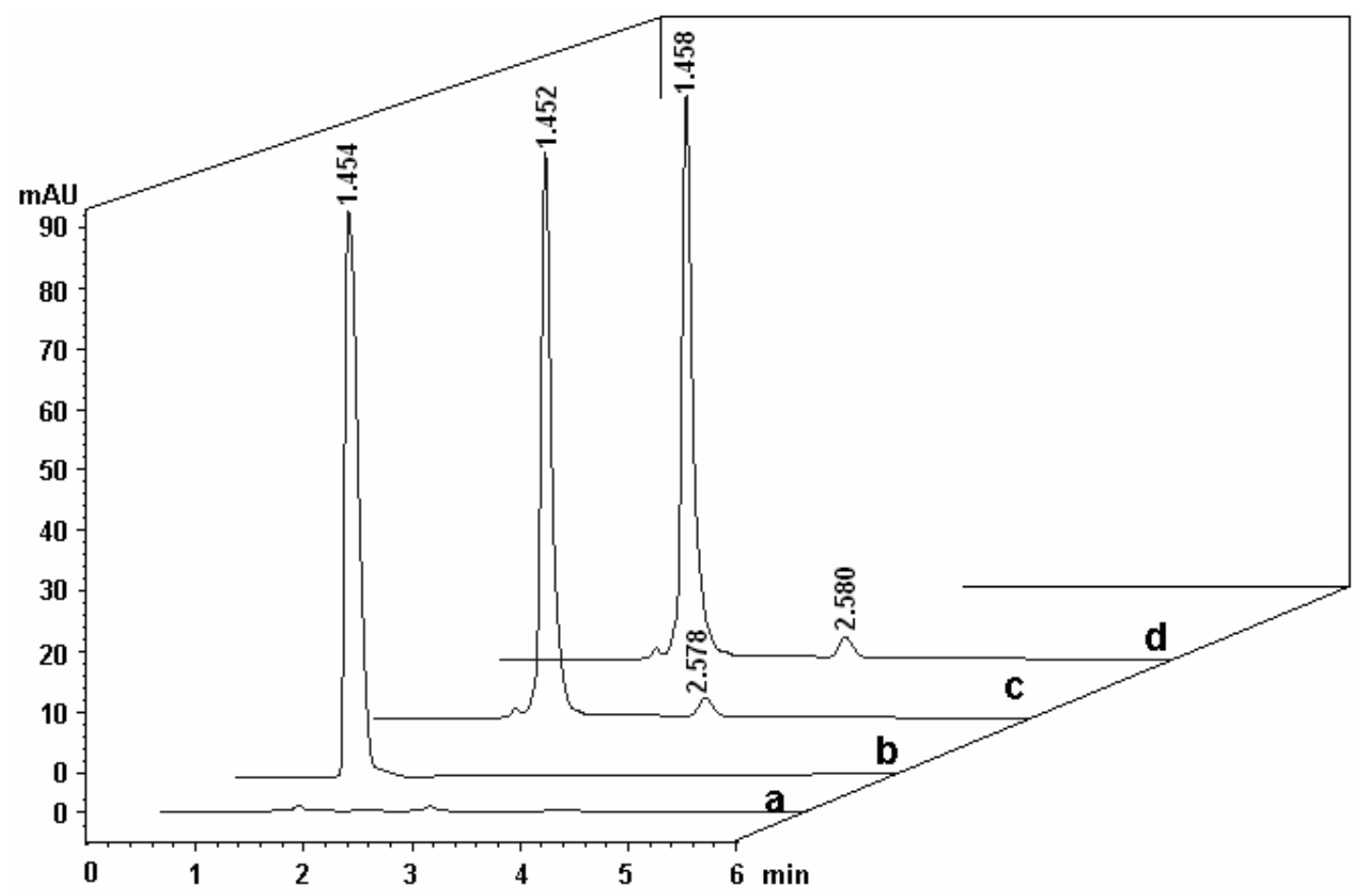

Fig. 1. The HPLC chromatograms at $263 \mathrm{~nm}$ of: blank solution (a), sodium picosulfate standard (b), and products during alkaline hydrolysis in $0.5 \mathrm{moldm}^{-3}$ of $\mathrm{NaOH}$ at $40{ }^{\circ} \mathrm{C}$ and $5 \mathrm{~min}(\mathrm{c}), 10 \mathrm{~min}(\mathrm{~d})$. It is noticeable sodium picosulfate at $t_{\mathrm{r}}=1.454 \mathrm{~min}$ and degradation product sodium-4-((2-pyridinyl)(4-hydroxiphenyl)methyl)phenylsulfat) at $t_{\mathrm{r}}=2.578 \mathrm{~min}$ 


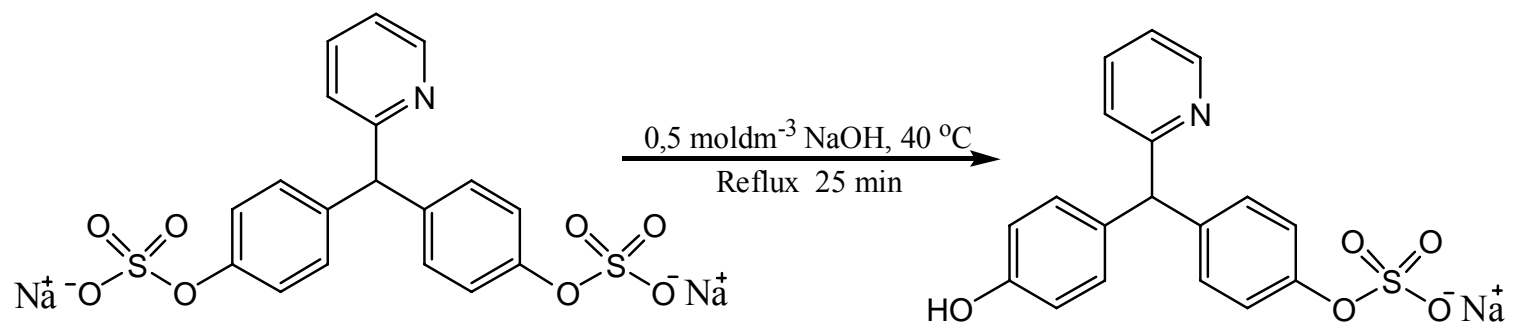

$\mathrm{A}$

Fig. 2. Proposed scheme of sodium picosulfate degradation process in alkaline solutions

The chromatographic parameters such as the efficiency column and the peak asymmetry were reconsidered for the sodium picosulfate standard (Fig. 1b). According to the obtained value of Number of Theoretical Plato $(\mathrm{N}=1144)$, the conclusion is that the efficiency column is satisfactory $($ HETP $=0.2184)$. The asymmetry peak value of 0.368 indicates that the peak is not ideally symmetric, that is, it is not Gauss's peak. Having in mind that $W_{\mathrm{ab}}<W_{\mathrm{bc}}$, this means that there is a certain interaction between the stationary phase and the investigated component. $k^{\prime}$ values were found to be 2.80 and 4.95 for sodium picosulfate and sodium-4-((2-pyridinyl)(4-hydroxiphenyl)methyl)phenylsulfat), respectively. The value of selectivity $(\alpha)$ was 1.77 .

The good linearity was obtained between the peak areas and the concentrations. The linear regression equation (eq. 1) obtained with a regression coefficient $(r)$ of 0.9933 was:

$$
A_{263}=\left[21395.35 \times C\left(\mathrm{mgcm}^{-3}\right)+294.005\right]
$$

Beer's law was obeyed in the range of decade $10-100 \mu \mathrm{gcm}^{-3}$. The chromatogram of sodium picosulfate was not changed in the presence of common excipients used in the pharmaceutical preparations. The chromatogram of the pure drug sample was matched with the formulation samples in the mobile phase. The calculated $t$-values of 1.468 were found to be less than that of the tabulated $t$-values $(t=2.225)$. Therefore, the proposed analytical method is specific and selective for the drug. The linearity range for sodium picosulfate estimation was found to be $10-100 \mu_{\mathrm{gcm}}{ }^{-3}$ $(r=0.9933)$. Goodness of the fit of the regression equations was supported by high regression coefficient values.

The accuracy of the method was checked by determining recovery values. Series of solution were made containing 80,100 and $120 \%$ of sodium picosufate regarding the declared content.
The accuracy ranged from 40 to $60 \mu \mathrm{gcm}^{-3}$ (Table $1)$. The excellent mean $\%$ recovery values, close to $100 \%$, and their low standard deviation values $(\mathrm{SD}<1.0)$ represent high accuracy of the analytical methods. The validity and reliability of the proposed methods were further assessed by recovery studies via the standard addition method. The mean \% recoveries (\% RSD) for the concentration of $50 \mu \mathrm{g} \mathrm{cm}^{-3}$ are shown in Table 2. These results revealed that any small change in the drug concentration in the solutions could be accurately determined by the proposed analytical methods.

Precision was determined by studying the reproducibility and the intermediate precision. Reproducibility (\% RSD) ranged from 40 to $60 \mu \mathrm{g} \mathrm{cm}^{-3}$ (Table 3 ). The reproducibility results indicated the precision under the same operating conditions over a short interval of time and the inter-assay precision. The intermediate precision expresses within laboratory variations in different days and in different instruments. In the intermediate precision study, \% RSD values were not more than $2.0 \%$ in all the cases. RSD values found for the proposed analytical method were well within the acceptable range indicating that the method has excellent reproducibility and the intermediate precision.

Table 3

System precision study $(n=10)$

\begin{tabular}{ccccc}
\hline \hline $\begin{array}{c}\text { Concentration } \\
\left(\mu \mathrm{gcm}^{-3}\right)\end{array}$ & \multicolumn{2}{c}{$\begin{array}{l}\text { Estimated concentration } \\
\text { Intra-day reproducibility } \\
\text { \% R.S.D., } n=10\end{array}$} & $\begin{array}{c}\text { Intra-instrument } \\
\text { reproducibility } \\
\text { \% R.S.D., } n=10\end{array}$ \\
\cline { 2 - 4 } & day 1 & day 2 & day 3 & \\
\hline \multirow{2}{*}{40} & 39.65 & 39.94 & 40.48 & $38.96(0.89)$ \\
& $(0.81)$ & $(0.67)$ & $(0.51)$ & \\
\multirow{2}{*}{50} & 49.85 & 50.32 & 49.88 & $50.35(1.41)$ \\
& $(0.05)$ & $(0.21)$ & $(0.08)$ & \\
60 & 60.55 & 60.51 & 60.15 & $60.34(1.55)$ \\
& $(0.18)$ & $(0.84)$ & $(0.08)$ & \\
\hline \hline
\end{tabular}


The limits of detection (LOD) and quantification (LOQ) were evaluated using the following equations [19-22]:

$$
L O D=3.3 \frac{S_{0}}{b} \quad L O Q=10 \frac{S_{0}}{b}
$$

were $S_{0}$ is the standard deviation of the calibration line and $b$ is the slope. They were found to be 0.086 and $0.258 \mu \mathrm{gcm}^{-3}$, respectively.

\section{Applicability of the proposed method}

The proposed method was applied for the determination of sodium picosulfate in pharmaceuti- cal formulations using the direct calibration curve. As it can be seen in Table 4, the results obtained for this method are in accordance with the official potentiometric titration. The results of the proposed method were statistically compared with this of the official method using a point hypothesis test $[23,24]$. Table 4 shows that the calculated $F$ and $t$ values at the $95 \%$ confidence level are less than the theoretical ones, confirming no significant differences between the performance of the proposed method and the official method.

Table 4

Determination of sodium picosulfate by the HPLC and the official methods (potentiometric titration)

\begin{tabular}{cc|c|c|c|c|c|c|c}
\hline $\begin{array}{c}\text { Pharmaceutical } \\
\text { preparation }\end{array}$ & $\begin{array}{c}\text { Taken, } \\
\mu \mathrm{gcm}^{-3}\end{array}$ & $\begin{array}{c}\text { Sodium picosulfate found by HPLC } \\
x \pm \mathrm{SD}, \mu \mathrm{g} \cdot \mathrm{cm}^{-3}\end{array}$ & $\begin{array}{c}\mathrm{RSD}^{\mathrm{a}} \\
\%\end{array}$ & $\begin{array}{c}\text { Recovery } \\
\%\end{array}$ & $F$ value & $t$ value & $\begin{array}{c}\text { Potentiometric titration } \\
x \pm \mathrm{SD}, \mu \mathrm{g} \cdot \mathrm{cm}^{-3}\end{array}$ \\
\hline $\begin{array}{c}\text { Sodium } \\
\text { picosulfate }\end{array}$ & 50 & $51.20 \pm 0.02$ & 2.16 & 102.41 & 1.36 & 0.609 & $51.30 \pm 0.01$ \\
\hline \hline
\end{tabular}

${ }^{a}$ Data are based on the average obtained from five determinations;

${ }^{\text {b }}$ Theoretical $F$ value $\left(v_{1}=4, v_{2}=4\right)$ and $t$ value $(v=8)$ at the $95 \%$ confidence level are 6.39 and 2.306 , respectively

\section{Kinetics of the sodium picosulfate degradation}

The degradation sodium picosulfate during alkaline hydrolysis and kinetics investigation was carried out in sodium hydroxide solutions of 0.1 , 0.5 and 1.0 moldm $^{-3}$, at different temperatures $\left(25^{\circ} \mathrm{C}, 40^{\circ} \mathrm{C}\right.$ and $\left.60{ }^{\circ} \mathrm{C}\right)$, by monitoring the parent compound itself.

For sodium picosulfate hydrolysis in 0.5 moldm ${ }^{-3}$ of $\mathrm{NaOH}$ at $40{ }^{\circ} \mathrm{C}$ the linear relationship was obtained by plotting the $\log$ concentrations of the remaining against time (Fig. 3).

Since the hydrolysis was performed in a large excess of $\mathrm{NaOH}\left(0.5\right.$ moldm $\left.^{-3}\right)$, it follows a pseudo-first order reaction rate which is the term used when two reactants are involved in the reaction but one of them is in such a large excess (i.e. $\mathrm{NaOH})$ that any change in its concentration is negligible compared with the change in concentration of the other reactant (i.e. drug).

Different parameters that affect the rate of the reaction were studied. The effect of temperature was studied by conducting the reaction at different temperatures using different concentrations of the alkaline solution (Figs. 3, 4).

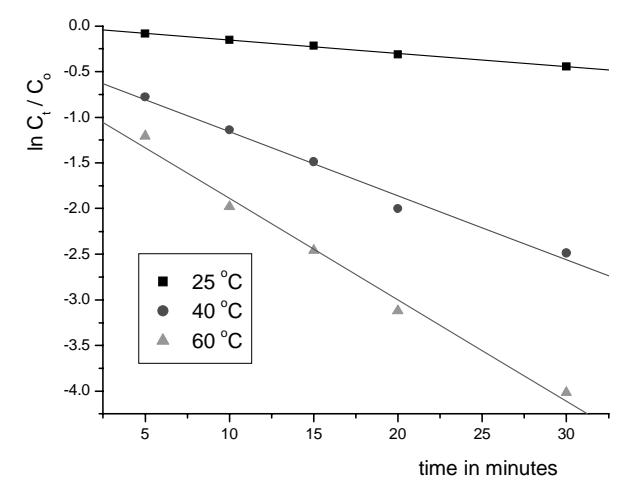

Fig. 3. First order plot of the sodium picosulfate with 0.1 moldm $^{-3}$ of $\mathrm{NaOH}$ at different temperatures

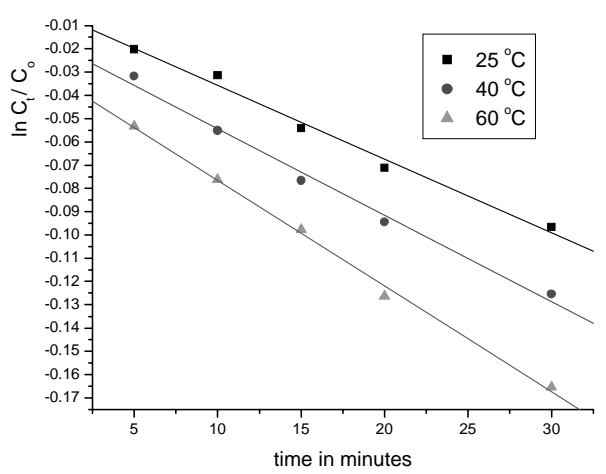

Fig. 4. First order plot of the sodium picosulfate with 0.5 moldm $^{-3}$ of $\mathrm{NaOH}$ at different temperatures 
At each temperature the rate constant was calculated and then $\log$ of rate constant was plotted against the reciprocal of the temperature in Kelvin units (Arrhenius plot (Fig. 5)) to demonstrate the effect of temperature on the rate constant.

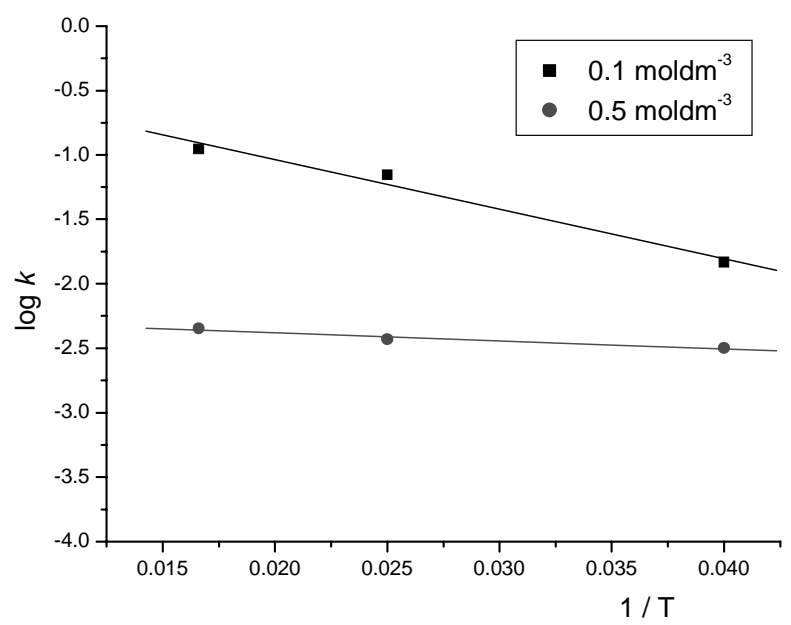

Fig. 5. Arrhenius plot for the sodium picosulfate with 0.1 and 0.5 moldm $^{-3}$ of $\mathrm{NaOH}$

The energy of activation was determined by calculating the rate constant [25] from the following (eq. 2) equation:

$$
\log \frac{K_{2}}{K_{1}}=\frac{E_{a}}{2.303 R}\left(\frac{T_{2}-T_{1}}{T_{1} T_{2}}\right)
$$

where $E_{a}$ is the activation energy, $T_{1}$ and $T_{2}$ are the two temperature degrees in Kelvin, $R$ is the gas constant, and $K_{1}$ and $K_{2}$ are the rate constants at the two temperatures used.

The calculated $E_{\mathrm{a}}$ was found to be 83.193 $\mathrm{kJ} \mathrm{mol}^{-1}$, suggesting the instability of sodium picosulfate in alkaline medium. Another factor that affects the rate of the reaction is the alkaline strength of $\mathrm{NaOH}$, thus different concentrations of $\mathrm{NaOH}$ solutions were used to study the hydrolysis increased with an increasing $\mathrm{NaOH}$ concentration, although the effect was minor compared to the effect of temperature (Figs. 3, 4 and Table 5). In conclusion, the alkaline hydrolysis of sodium picosulfate and its alkaline degradation product sodium-4-((2-pyridinyl)(4-hydroxiphenyl)methyl)phenylsulfat) were found to follow a pseudo-first order reaction rate. Also the reaction rate increases in the temperature and the strength of the alkaline solution.
Table 5

Kinetic and statistical data of sodium picosulfate alkaline hydrolysis, with different concentrations of $\mathrm{NaOH}$ at different temperatures

\begin{tabular}{|c|c|c|c|c|}
\hline $\begin{array}{c}\text { Temperature } \\
\text { (C) }\end{array}$ & $\begin{array}{l}a \text { or } k \text { (the rate } \\
\text { constants) }\end{array}$ & $b$ & $r$ & SD \\
\hline \multicolumn{5}{|c|}{$0.1 \mathrm{moldm}^{-3} \mathrm{NaOH}$} \\
\hline 25 & -0.0147 & -0.0059 & -0.9983 & 0.009 \\
\hline 40 & -0.0702 & -0.4551 & -0.9925 & 0.095 \\
\hline 60 & -0.1111 & -0.7769 & -0.9946 & 0.128 \\
\hline \multicolumn{5}{|c|}{0.5 moldm $^{-3} \mathrm{NaOH}$} \\
\hline 25 & -0.0031 & -0.0040 & -0.9938 & 0.004 \\
\hline 40 & -0.0037 & -0.0171 & -0.9952 & 0.003 \\
\hline 60 & -0.0045 & -0.0311 & -0.9982 & 0.004 \\
\hline \multicolumn{5}{|c|}{1.0 moldm $^{-3} \mathrm{NaOH}$} \\
\hline 25 & - & - & - & - \\
\hline 40 & - & - & - & - \\
\hline 60 & - & - & - & - \\
\hline
\end{tabular}

\section{CONCLUSION}

A new RP-HPLC method was developed and validated for the determination of sodium picosulfate in the solid pharmaceutical products. The analytical method is a simple, sensitive and selective method suitable for application in a drug manufacturing quality control or regulatory analysis laboratory of sodium picosulfate either in the pure powdered form or available pharmaceutical dosage forms. The HPLC assay method was developed for the identification and separation of sodium picosulfate its potential impurity or degradation product.

The alkaline hydrolysis of sodium picosulfate was found to follow a pseudo-first order reaction rate. Also, the reaction rate increases with the increase in the temperature and the strength of the alkaline solution. Sodium picosulfate was found to be highly susceptible to 0.5 moldm $^{-3}$ of $\mathrm{NaOH}$. At the beginning of alkaline hydrolysis of sodium picosulfate with 1 moldm $^{-3} \mathrm{NaOH}$, the concentration of the active substance was so low that was not determined by eq. 1 .

However, general degradation from different cases (acid hydrolysis, oxidation and UVphotolysis) is possible but needs to be studied further by the developed HPLC method. 
Acknowledgements. This work was supported by the Ministry of Science of the Republic of Serbia, project TR-19035. The authors are grateful for the financial support provided by this Ministry.

\section{REFERENCES}

[1] European Pharmacopoeia, Directorate for the Quality of Medicines of the Council of Europe, Strasbourg, France, Fourth ed., Supplement 4.6, Monograph 01/2004:0929.

[2] United States Pharmacopoeia, 27th ed., Rockville, MD, USA, 2003, p. 1102.

[3] J. Morton, The detection of laxative abuse, Ann Clin Boichem, 24 (1), 107-108 (1987).

[4] R. Kok, D. Faber, Qualitative and quantitative analysis of some synthetic chemically acting laxatives in urine by gas-chromatography-mass spectrometry, J. Chromatogr., 222, 389-398 (1981).

[5] R. Fullinfaw, R. Bury, R. Moulds, Screening procedure for stimulant laxatives in urine using high-performance liquid chromatography with diode array detection, $J$. Chromatogr., 433, 131-140 (1988).

[6] C. Pijnenburg, A. Duchateau, J. Conemans, F. Gerkens, R. Snoeren, C. Barella, Systematische toxicologische analyse van geneesmiddelen met behulp van HPLC en UV-detectie, Ziekenhuisfarmacie, 6 (1), 1-4 (1990).

[7] R. Jauch, R. Hankwity, K. Beschke, H. Pelzer, Bis-(phydroxyphenyl)-pyridyl-2-methane: the common laxative principle of bisacodyl and sodium picosulfate, Arzneim Forsch, 25 (11), 1796-1800 (1975).

[8] L. Stolk, K. Hoogtanders, Detection of laxative abuse by urine analysis with HPLC and diode array detection, Pharm. World Sci., 21 (1), 40-43 (1999).

[9] M. Blanco, J. Coello, H. Iturriaga, S. Maspoch, C. Meseda Perez, Use of inverse multiple linear regression (ILS) for the analytical control of pharmaceutical preparations. UV-visible spectrophotometric quantitation of an active principal in the presence of absorbing excipients, $J$. Chromatogr. A, 799, 301 (1998).

[10] K. Altria, M. Kelly, B. Clark, Current applications in the analysis of pharmaceuticals by capillary electrophoresis, Trends Anal. Chem., 17, 214-226 (1998).

[11] M. Blanco, J. Coello, H. Iturriaga, S. Maspoch, M. Romero, Analytical control of a pharmaceutical formulation of sodium picosulfate by caillary zone electrophoresis, $J$. Chromatogr. B, 751, 29-36 (2001).
[12] The European Agency for the Evaluation of Medicinal Products. ICH Topic Q2B Note for Guideline on Validation of Analytical Procedures: Methodology GPMP/ICH/ 281/95, 1996.

[13] Jugoslovenska farmakopeja, V ed., Beograd, Savremena administracija, 2000.

[14] S. Bolton, Pharmaceutical Statistics: practical and clinical application, III ed., Marcel Dekker, New York, 1997, pp. 216.

[15] Ph. Hubert, J. Nguyen-Huu, B. Boulanger, E. Chapuzet, P. Chiap, N. Cohen, P. Compagnon, W. Dewe, M. Feinberg, M. Lallier, M. Laurentie, N. Mercier, G. Muzard, C. Nivet, L. Valat, STP Pharma Pratiques, 13 (3), 101 (2003).

[16] E. Chapuzet, N. Mercier, S. Bervoas-Martin, B. Boulanger, P. Chevalier, P. Chiap, D. Grandjean, Ph. Hubert, P. Lagorce, M. Lallier, M. Laparra, M. Laurentie, J. Nivet, STP Pharma Pratiques, 7, 169 (1997).

[17] Ph. Hubert, P. Chiap, J. Crommen, B. Boulanger, E. Chapuzet, N. Mercier, B. Bervoas-Martin, P. Chevalier, D. Grandjean, P. Lagorce, M. Lallier, M. Laparra, M. Laurentie, J. Nivet, The SFSTP guide on the validation of chromatographic methods for drug bioanalysis: from the Washington Conference to the Laboratory, Anal. Chem. Acta, 391, 135-148 (1999).

[18] ISO 5725-1, Application of the statistics-accuracy (trueness and precision) of the results and methods of measurement. Part 1: General principles and definitions, International Organization for Standardization (ISO), Geneva, Switzerland.

[19] J. Ermer, Validation in pharmaceutical analysis, $J$. Pharm. Biomed. Anal, 24, 755-769 (2001).

[20] D. Perez-Bendito, M. Silva, Kinetic Methods in Analytical Chemistry, Ellis Hor wood, Chichester, 1988, pp. 254.

[21] H. Mottola, Kinetic Aspects of Analytical Chemisry, Wiley, New York, 1988, pp. 40.

[22] V. Thomsen, D. Schatzlein, D. Mercuro, Spectroscopy, 18, 112 (2003).

[23] C. Hartmann, J. Smeyers-Verbeke, W. Penninckx, Y. Heyden, P. Vankeerberghen, D. Massart, Anal. Chem. 67, 4491 (1995).

[24] D. Skoog, D. West, F. Holler, Fundamentals of Analytical Chemistry, Saunders College Publishing, Philadelpia, 1996, pp. 51.

[25] A. Florence, D. Attwood, Physical Principles of Pharmacy, II ed., Macmillan Press, 1998. 